\title{
Vegetative impacts upon bedload transport capacity and channel stability for differing alluvial planforms in the Yellow River source zone
}

\author{
Zhi Wei Li ${ }^{1}$, Guo An Yu ${ }^{2}$, Gary Brierley ${ }^{3}$, and Zhao Yin Wang ${ }^{4}$ \\ ${ }^{1}$ School of Hydraulic Engineering, Key Laboratory of Water Sediment Sciences and Water Disaster Prevention of Hunan \\ Province, Changsha University of Science \& Technology, Changsha, China \\ ${ }^{2}$ Key Laboratory of Water Cycle and Related Land Surface Processes, Institute of Geographic Sciences and Natural \\ Resources Research, Chinese Academy of Sciences, Beijing, China \\ ${ }^{3}$ School of Environment, University of Auckland, Auckland, New Zealand \\ ${ }^{4}$ State Key Laboratory of Hydroscience and Engineering, Tsinghua University, Beijing, China
}

Correspondence to: Guo An Yu (yuga@igsnrr.ac.cn)

Received: 6 December 2015 - Published in Hydrol. Earth Syst. Sci. Discuss.: 1 February 2016

Revised: 29 June 2016 - Accepted: 8 July 2016 - Published: 28 July 2016

\begin{abstract}
The influence of vegetation upon bedload transport and channel morphodynamics is examined along a channel stability gradient ranging from meandering to anabranching to anabranching-braided to fully braided planform conditions along trunk and tributary reaches of the Upper Yellow River in western China. Although the regional geology and climate are relatively consistent across the study area, there is a distinct gradient in the presence and abundance of riparian vegetation for these reaches atop the QinghaiTibet Plateau (elevations in the study area range from 2800 to $3400 \mathrm{~m}$ a.s.1.). To date, the influence of vegetative impacts upon channel planform and bedload transport capacity of alluvial reaches of the Upper Yellow River remains unclear because of a lack of hydrological and field data. In this region, the types and pattern of riparian vegetation vary with planform type as follows: trees exert the strongest influence in the anabranching reach, the meandering reach flows through meadow vegetation, the anabranching-braided reach has a grass, herb, and sparse shrub cover, and the braided reach has no riparian vegetation. A non-linear relation between vegetative cover on the valley floor and bedload transport capacity is evident, wherein bedload transport capacity is the highest for the anabranching reach, roughly followed by the anabranching-braided, braided, and meandering reaches. The relationship between the bedload transport capacity of a reach and sediment supply from upstream exerts a significant influence upon channel stability. Bedload transport
\end{abstract}

capacity during the flood season (June-September) in the braided reach is much less than the rate of sediment supply, inducing bed aggradation and dynamic channel adjustments. Rates of channel adjustment are less pronounced for the anabranching-braided and anabranching reaches, while the meandering reach is relatively stable (i.e., this is a passive meandering reach).

\section{Introduction}

Transitions in river character and behavior are a key focal point of enquiry in fields such as geomorphology, hydrology, and sedimentology. Such concerns have significant management applications, especially relating to issues such as management of flood risk and sedimentation hazards. These issues are likely to become even more pronounced in the future, as rivers adjust in response to climate and land use changes, and management actions. Putting aside concerns for terminological issues associated with differentiation of river types and their morphological attributes (see Lewin and Ashworth, 2014; Carling et al., 2014; Tadaki et al., 2014), process-based understandings of morphodynamic adjustments are required to address concerns for prospective future river changes (Beechie et al., 2010). Here we evaluate the influence of riparian vegetation upon process interac- 
tions along relatively understudied reaches of the Upper Yellow River atop the Qinghai-Tibet Plateau in western China. Qualitative description and analysis of this complex influence on bedload transport capacity remains unclear to our knowledge.

Channel bars are products of instream deposition of bedload materials, whether at the channel margin (bank-attached forms) or mid-channel bars (Brierley and Fryirs, 2005). Typically, bars mutually adjust with channel geometry, such that they scale to the size of the channel in which they form (Task Force on Bed Forms in Alluvial Channels, 1966; Nicholas et al., 2013). If these features become vegetated and stabilized, they are referred to as islands (Fryirs and Brierley, 2012). Unit bars (migrating lobate bed forms with heights and lengths that scale with channel depth and width) are differentiated from larger, more complex compound bars (e.g., Bridge, 1993; Brierley, 1989, 1991; Brierley and Hickin, 1991; Smith, 1974). Compound bars are products of multiple phases of accretion and reworking, with stacked sequences of unit bar, dune, and smaller bed form deposits that are often trimmed at their margins by bank erosion processes or dissected by chute channels (Ashworth et al., 2011; Best et al., 2003; Bridge, 2003; Brierley and Fryirs, 2005; McGowen and Garner, 1970; Reesink et al., 2014; Sambrook et al., 2009). Various studies have characterized the main morphological elements of large bars and islands, while other studies have developed conceptual models of bar evolution (e.g., Ashworth et al., 2000; Gurnell et al., 2001; Latrubesse and Franzinelli, 2002; Mertes et al., 1996).

There is notable variability in the presence, form, and hydraulic/sedimentologic (morphodynamic) role of bars along the continuum of channel planform (Bridge, 1993; Brierley, 1996). By definition, as suspended-load rivers have limited bedload-calibre materials, they have very few, if any, bars. The prominence of fine-grained (silt-clay) deposits under low energy conditions (often very low channel gradient) promotes passive channel behavior, typically with a low sinuosity, passive meandering, or anabranching (anastomosing) planform (Eaton et al., 2010; Fryirs and Brierley, 2012; Makaske, 2001; Wang et al., 2005). Patterns of bar formation in mixed-and bedload-dominated rivers reflect the flowsediment balance along any given reach, with a spectrum of planform types ranging from active meandering and wandering variants through to fully braided rivers (see Ashworth, 1996; Ashworth and Lewin, 2012; Burge, 2006; Church and Rice, 2009). Braiding results from the inability of flow to transport all sediments that are made available to the channel, such that mid-channel sedimentation occurs (i.e., competence and/or capacity limits are exceeded). Recurrent reworking of bedload materials via thalweg shift during flood events alters the number, shape, and location of bars. Bar dissection and avulsion create multi-thread channel systems with a disorderly river planform, extremely unstable bars, and inconstant flow paths (Ashmore, 1991; Ashworth et al., 2000; Jerolmack and Mohrig, 2007).
If channel boundary conditions induce sufficient bank strength, and flows are able to transport available bedload sediments, the river adopts a configuration with betterdefined, less mobile channels with a much lower widthdepth ratio, whether within a single-channel configuration (typically passive meandering) or a multi-channel anabranching configuration (Eaton et al., 2010; Song and Bai, 2015). Controversy abounds in our theoretical understanding of process controls upon anabranching river behavior (see Carling et al., 2014; Nicholas et al., 2013). While Huang and Nanson (2007) and Jansen and Nanson (2004, 2010) attributed an anabranching configuration to the least action principle, wherein channels adjust their form to transport available sediment in the most hydraulically efficient manner, Eaton and co-workers postulated an alternative theoretical framing in which anabranching channels adjust to minimize their capacity to transport materials (Eaton and Church, 2007; Eaton et al., 2004, 2010). It is not our concern here to address this issue directly. Rather, our focus lies with analysis of relationships between bedload transport capacity and channel morphodynamics along a continuum of channel planform types that is coincident with a gradation in riparian vegetation cover along the Upper Yellow River (Yu et al., 2014).

Bar stability is the key distinguishing attribute of braided and anabranching rivers. In some instances, vegetation may support the long-term development of stable sandbars within a stable multi-channel system - a variant of an anabranching river (Latrubesse, 2008; Nanson and Knighton, 1996; Murray and Paola, 2003; Tal and Paola, 2010). Vegetation increases flow resistance and stabilizes the channel bed and bank along anabranching rivers, thereby altering channel geometry, bedload transport rates, and the resulting rates and patterns of bed deposition or erosion. Once a particular morphology has been formed, the configuration of channels and associated distribution of bars and roughness elements fashion process responses to subsequent flood events (Hooke, 1986, 2015; Hooke and Yorke, 2011; Luchi et al., 2010). If critical threshold conditions are exceeded, alterations to the balance and patterns of erosion and deposition processes may bring about transitions to different planform types.

Mutual adjustments between patterns of vegetation types (size, spacing, and density) and flow-sediment dynamics (patterns and rates of erosion and deposition) vary at different positions on the valley floor. Vegetation encroachment by pioneer species and successional processes induce abiotic and biotic transitions in geomorphic processes from the unvegetated channel bed and bar surfaces to grassland, shrubs, and treed areas at the margins of bars/islands and on floodplains (Corenblit et al., 2007, 2011; Gurnell, 2014; Hickin, 1984; Hupp and Osterkamp, 1996; Millar, 2000; Tooth and Nanson, 2000). Vegetation attributes influence the pattern of roughness elements and the associated distribution of flow energy, thereby affecting the distribution of erosional and depositional processes, and resulting morphological attributes 
Table 1. Characteristics of the four study reaches (flood season is June-September).

\begin{tabular}{|c|c|c|c|c|c|}
\hline $\begin{array}{l}\text { Alluvial } \\
\text { reach }\end{array}$ & $\begin{array}{l}\text { Planform } \\
\text { type }\end{array}$ & $\begin{array}{r}\text { Catchment } \\
\text { area } \\
\left(\mathrm{km}^{2}\right)\end{array}$ & $\begin{array}{r}\text { Flood-season } \\
\text { mean } \\
\text { discharge } \\
\left(\mathrm{m}^{3} \mathrm{~s}^{-1}\right)\end{array}$ & $\begin{array}{l}\text { Channel } \\
\text { gradient }\end{array}$ & $\begin{array}{l}\text { Vegetation } \\
\text { cover }\end{array}$ \\
\hline Dari & $\begin{array}{l}\text { anabranching- } \\
\text { braided }\end{array}$ & 45020 & 270 & 0.0012 & $\begin{array}{l}\text { dense grasses/ } \\
\text { sparse brush }\end{array}$ \\
\hline Maqu & anabranching & 86000 & 920 & 0.0005 & dense trees \\
\hline Lanmucuo & meandering & 660 & 15 & 0.0015 & dense grass \\
\hline Daheba & braided & 5200 & 70 & 0.0018 & non-vegetation \\
\hline
\end{tabular}

(including the grain size distribution of bed/bar materials). Hence, vegetative controls influence the stability and behavior of the alluvial bed and bars, and the influence of vegetation upon flow-sediment interactions vary for differing planform types (Gran and Paola, 2001; Gradzinski et al., 2003; Jang and Shimizu, 2007; McBride et al., 2007).

Although the prominence of seasonal low-flow stages and nutrient-rich fine sands may support the growth of annual or perennial herbs and shrubs on mid-channel and transverse bars in braided rivers, this sparse vegetation cover has a negligible impact upon sediment deposition and erosion patterns, and is removed easily at flood stage (Coulthard, 2005). This mutual interaction between vegetation and erosiondeposition can be viewed as a threshold condition: if sufficient vegetation establishment occurs, resistance may exceed the erosion-deposition capability of a normal flood such that stabilization ensues, prospectively altering sedimentation patterns, increasing bank strength, and reducing channel width-depth ratio (Gran and Paola, 2001; Coulthard, 2005; Eaton et al., 2010). In anabranching channels the vegetation cover on mid-channel bars inhibits lateral migration, inducing a stable branching channel condition. During lower frequency floods, when bars are partially or completely submerged by flow, vegetation increases flow resistance, traps sediment, and inhibits erosion.

This study builds upon previously reported exploratory analyses of river diversity in the source zone of the Yellow River (Blue et al., 2013; Brierley et al., 2016; Li et al., 2013; Yu et al., 2014). In this region, herbs and sparse shrubs that grow on the sand/gravel bars of braided rivers have a trivial influence upon channel morphodynamics, while establishment of dense shrubs and sparse trees on sand/gravel bars promotes the emergence of anabranching channel configurations. Building on these previous observations, here we appraise process interactions along a vegetative gradient of river morphologic adjustments for four reaches: the Dari and Maqu reaches of the Yellow River main stream, and the Daheba and Lanmucuo river tributaries of the Upper Yellow River (Table 1). The Dari reach has a semi-stable braided channel, where sandbars are covered by herbaceous vegetation and sparse shrubs. The Maqu reach has a very sta- ble anabranching channel with dense willows (Salix atopantha) on sandbars. The study reach along the Lanmucuo River has a stable gravel meandering river with herb coverage. The study reach along the Daheba River has a very unstable gravel braided channel without vegetation cover. We develop and apply a simplified model to explain the interaction between sediment transport capacity and river bed deposition in these reaches, examining the effect of vegetation resistance and adjustment of fluvial hydraulic geometry. From this, we quantitatively analyze the stability and evolution of braided, anabranching, and meandering reaches during flood events.

\section{Study area and methods}

Upstream of Tangnaihai hydrological station the source zone of the Yellow River drains an area of $132000 \mathrm{~km}^{2}$ (see Fig. 1a). In the 1950s, the Yellow River Conservancy Commission established four hydrological stations along the Yellow River in this area, namely (from upstream to downstream), Huangheyan station in Maduo County, Jimai station in Dari County, Maqu station in Maqu County, and Tangnaihai station in Xinhai County. The reach from Huangheyan to Jimai station is $325 \mathrm{~km}$ long and drains an area of $24089 \mathrm{~km}^{2}$. In this reach the valley is quite wide, with semi-braided and semi-anabranching planform morphologies characterized by disordered channels with many bars (Brierley et al., 2016). The reach from Jimai to Maqu is $585 \mathrm{~km}$ long and drains an area of $41029 \mathrm{~km}^{2}$. The upper section of this reach has a deeply incised (confined), sinuous valley between the Anyemaqen and Bayan Har Mountains. Flowing into the Ruoergai alluvial basin, there is a diverse array of planform types (Blue et al., 2013; Brierley et al., 2016; $\mathrm{Li}$ et al., 2013). The reach from Maqu to Tangnaihai station is $373 \mathrm{~km}$ long and drains an area of $35924 \mathrm{~km}^{2}$. Most of this reach comprises a steep and incised canyon, with many deeply carved meander bends.

For this study, field investigations of vegetative influences upon bed/bar geomorphic processes were conducted 4 times in the summers of 2011-2014. Particle size distributions of bed and bank materials size were analyzed using a laser particle size analyzer (Mastersizer 2000) and field sieves were 


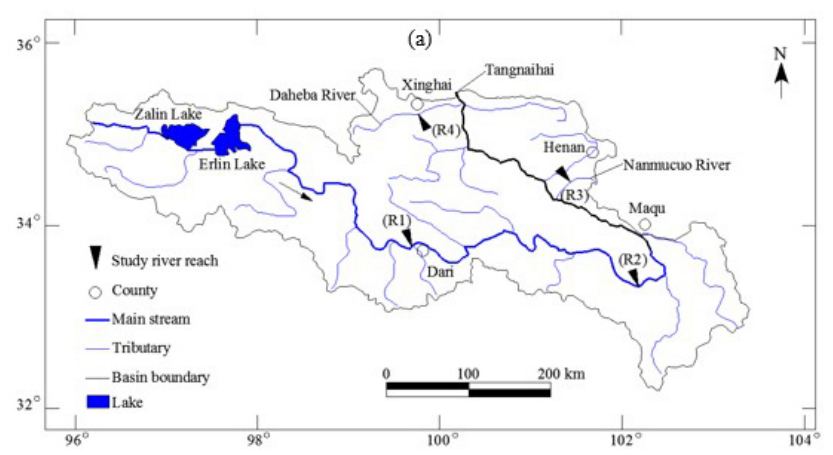

(b)
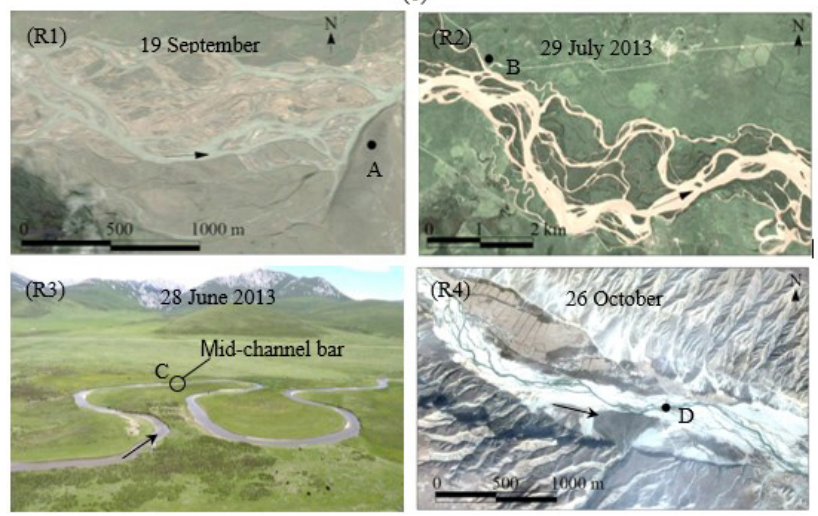

Figure 1. (a) The course of the Upper Yellow River. R1 is the Dari reach, R2 is the Maqu reach, R3 is the Lanmucuo River, and R4 is the Daheba River, (b) Planform morphology of the study reaches ( $\mathrm{R} 1$ is the Dari reach, R2 is the Maqu reach, R3 is the Lanmucuo River reach, and R4 is the Daheba River reach). R1, R2, and R4 are Google Earth images and R3 is a photograph taken from nearby hills. Points A-D are the location of photographs shown in Fig. 2.

used to test 10 samples of river bed and bank materials in each reach. As a supplement, photographs of gravel and cobbles on the bed/bar surface were taken to visually estimate bed particle size. To estimate bedload transport capacity, channel geometry was assessed in the field and from remote sensing images of the branching channel network (Google Earth images from 2005-2014, with a resolution of about $0.24 \mathrm{~m})$.

The best available hydrological data that could be accessed for this study were daily stage-discharge data from Jimai (1964-1985), monthly stage-discharge data from the Maqu (1959-1970), monthly cross section elevation change data from Shangcun station along the Daheba River $(1.8 \mathrm{~km}$ upstream from its confluence with the Yellow River, 20092011), and 2011-2014 field data for the Lanmucuo River (a tributary of the Yellow River in the Maqu-Tangnaihai section, at an elevation of 3400-4200 ma.s.l., for which upstream and mid-catchment reaches have a typically meandering channel, while the downstream reach has a confined bedrock channel). There are no intensive human activities in this area of the Yellow River source zone.
Table 2. Characteristics and bed material of alluvial channels in the four study reaches.

\begin{tabular}{lrccll}
\hline $\begin{array}{l}\text { Alluvial } \\
\text { reach }\end{array}$ & $\begin{array}{r}\text { Channel } \\
\text { width } \\
(\mathrm{m})\end{array}$ & $\begin{array}{r}\text { Water } \\
\text { depth } \\
(\mathrm{m})\end{array}$ & $\begin{array}{r}\text { Bed } \\
\text { material } \\
d_{50}(\mathrm{~m})\end{array}$ & $\begin{array}{l}\text { Branching } \\
\text { channels }\end{array}$ & Stability \\
\hline Dari & $450-1600$ & $1.0-3.0$ & 0.025 & $>5$ & semi-stable \\
Maqu & $300-1000$ & $2.0-5.0$ & 0.015 & $>3$ & very stable \\
Lanmucuo & $10-20$ & $0.3-1.0$ & 0.030 & $<=2$ & $\begin{array}{l}\text { very stable } \\
\text { unstable }\end{array}$ \\
Daheba & $150-500$ & $0.5-2.0$ & 0.060 & $>3$ & \\
\hline
\end{tabular}

\section{Basic characteristics of four alluvial reaches}

Figure $1 \mathrm{~b}$ shows the planform morphology of the four channel reaches. Figure 2 shows the channel morphology, pattern of bar types, and bed sediment. Basic channel characteristics of the study reaches are summarized in Table 2 .

The Dari reach has a semi-braided and semi-anabranching channel in a wide valley (Fig. $1-\mathrm{R} 1$ and Fig. 2 - R1). This anabranching-braided transition zone is considered to be semi-stable, with an active channel zone that is around $1 \mathrm{~km}$ wide. The braided part of the channel is made up of many small longitudinal and transverse bars, with multiple connected branching channels. In the anabranching part, the large bars/islands have a dense grassland vegetation. Given the extensive width of the active channel zone, annual floods during June-September exert negligible impacts upon these relatively stable surfaces.

The Maqu reach is located in a wide alluvial valley (1.5$3.0 \mathrm{~km}$ wide). The dense tree cover of the vegetated islands is indicative of a stable channel configuration (see Fig. 1 R2 and Fig. 2 - R2). During the flood season, tree trunks are partly submerged into water, but the trees are sufficiently dense to limit erosion. As a result, the anabranching system as a whole is quite stable with high bedload transport capacity.

The Lanmucuo River is a meadow meandering river with nearly $100 \%$ vegetation cover (see Fig. 1 - R3 and Fig. 2 $\mathrm{R} 3$ ). The root system of riparian grasses induces considerable protection from near-bank erosion. Field investigations from 2011-2014 indicate that the lateral migration induced by cantilever bank failure occurred at a rate of less than $0.2 \mathrm{~m} \mathrm{yr}^{-1}$. The gravel-bed channel has a low bedload transport rate in the flood season. In some local sections, mid-channel bars with dense grass coverage have developed at the apex of bends. The whole channel is quite stable, in spite of shortterm outer bank failures and long-term meander neck cutoffs.

The Daheba River has incised into the Gonghe-Xinhai sedimentary basin. Severe gully erosion has incised riverlacustrine sediments to a depth of 50-100 m, supplying large volumes of gravel/cobble to the middle and lower Daheba channel, inducing significant bed aggradation and the formation of a braided planform. Alluvial fans at gully outlets not only supply additional sediment, but also push the channel to the opposite side of the valley floor (a big fan is shown 

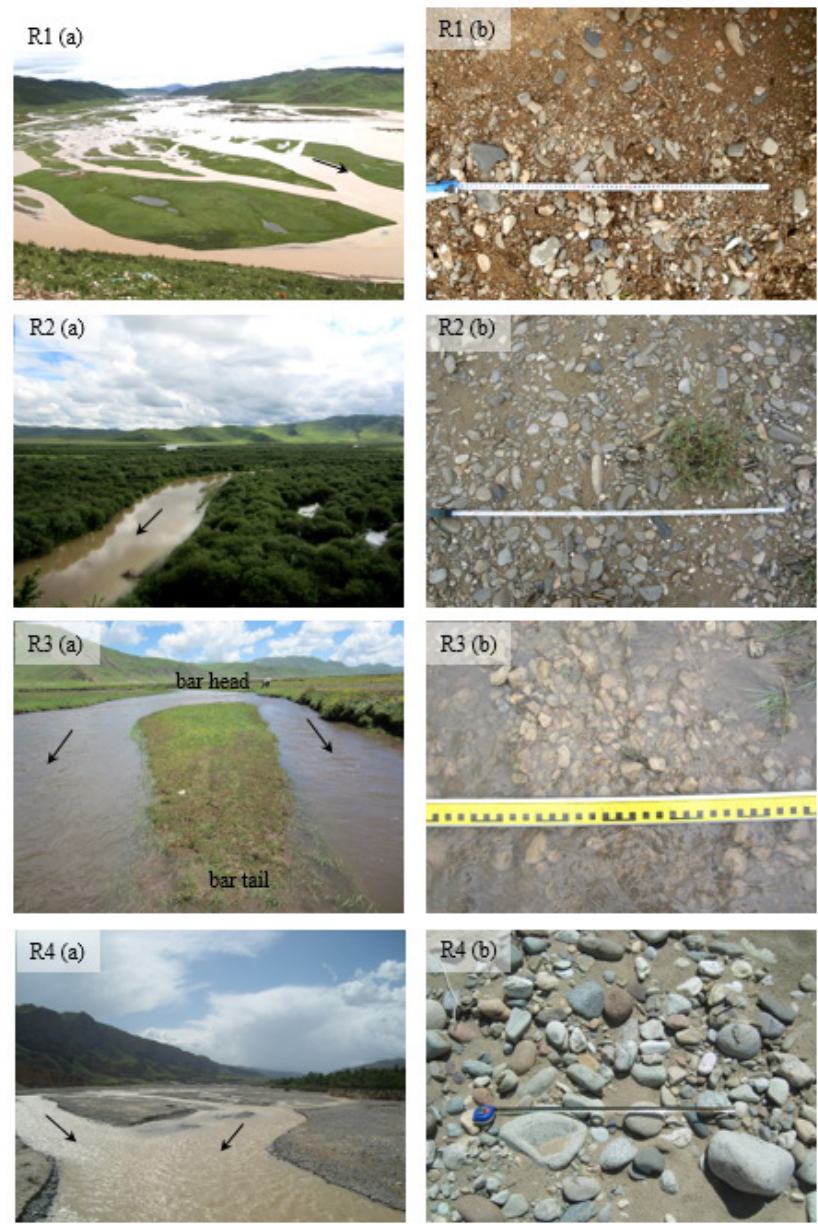

Figure 2. R1: channel morphology and gravel bed of the Dari reach (photographs taken on 2 July $2012,33.7553^{\circ} \mathrm{N}, 99.6414^{\circ} \mathrm{E}$; $3960 \mathrm{~m}$ elevation), R2: channel morphology and gravel bed of the Maqu reach (photographs taken on 8 July 2012, 33.3594 ${ }^{\circ} \mathrm{N}$, $102.0553^{\circ} \mathrm{E} ; 3465 \mathrm{~m}$ elevation), R3: channel morphology and gravel bed of a grass covered bar in the middle Lanmucuo River (photographs taken on 5 July 2012, $34.4287^{\circ} \mathrm{N}, 101.4663^{\circ} \mathrm{E}$; $3604 \mathrm{~m}$ elevation), R4: channel morphology and gravel bed of the middle Daheba River (photographs taken on 6 August 2011, $35.5169^{\circ} \mathrm{N}, 100.0183^{\circ} \mathrm{E} ; 2832 \mathrm{~m}$ elevation).

near D point in Fig. 1 - R4 and Fig. 2 - R4). As a result, the main branching channels are subjected to frequent and recurrent avulsion. Flows erode new small branching channels during the flood season, but a main channel coexists with several branching channels in the non-flood season. Unstable mid-channel bars are unvegetated other than sparse vegetation coverage (grass and shrubs) on riparian banks. The gravel-cobble bed and high bedload transport rate restrict vegetation establishment and growth, resulting in a typically unstable braided river.

Bank strength induced by sediment material mix and vegetation root networks exerts a critical influence upon the stability of alluvial channels (Eaton and Giles, 2009). Rein-

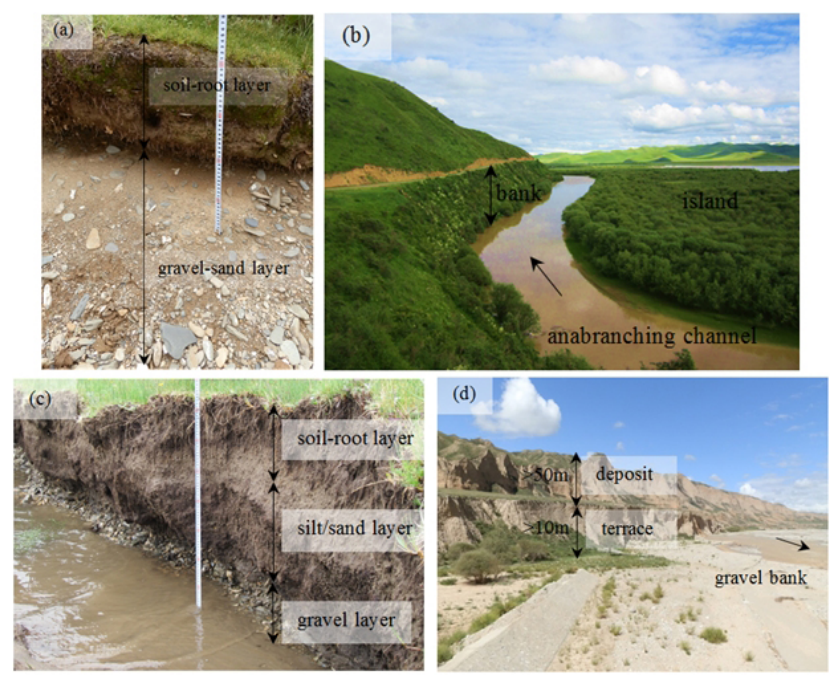

Figure 3. River bank of the study reaches (a) Dari reach, (b) Maqu reach, (c) Lanmucuo River reach, and (d) Daheba River reach.

forcement of bank strength reinforced by grass, shrub, and tree roots is related to the density, depth, and spatial structure of the root network (Abernethy and Rutherfurd, 2001). Figure 3 shows representative photographs of river banks in the four study reaches. The diverse bank material composition and vegetation cover affect the relative strength of banks and their capacity to resist near-bank flow scour. The river bank in the Dari reach has a two-layer structure, with a $20-30 \mathrm{~cm}$ deep soil-root layer ( $d_{50}$ is median size, $d_{50}=0.02 \mathrm{~mm}$ ) lying atop a gravel-sand layer $\left(d_{50}=6.0 \mathrm{~mm}\right)$ (Fig. 3a). The river bank in the Maqu reach has a dense grass, shrub, and tree cover (Fig. 3b), with no indication of flow scour in the flood season. The study reach along the Lanmucuo River has a typical composite bank sedimentology of a mixed load river (Fig. 3c). An upward-fining sequence is characterized by a basal gravel unit $\left(d_{50}=5.5 \mathrm{~mm}\right)$ extending to a $10-30 \mathrm{~cm}$ thick silt/sand layer $\left(d_{50}=0.03 \mathrm{~mm}\right)$ that is capped by a 10 $50 \mathrm{~cm}$ thick fine-grained soil-root complex $\left(d_{50}=0.02 \mathrm{~mm}\right)$. Conversely, the bank of the middle Daheba River has characteristic deposits of a bedload-dominated river, with noncohesive gravels and a sparse grass cover (Fig. 3d). Adjacent terraces that are more than $10 \mathrm{~m}$ high limit the capacity for channel widening, while actively supplying gravels. Mobile gravel banks influence the braided characteristics of the Daheba River. In summary, bank strength of the four study reaches varies from high to low as follows: Maqu reach, Lanmucuo River, Dari reach, and Daheba River.

\section{Estimation of bedload transport capacity}

Given the lack of observed data of bedload transport rate, bedload transport capacity has been estimated for a rectangular cross section using the theoretical bedload formulae 
Table 3. Estimation of hydraulic coefficients and bedload transport rates.

\begin{tabular}{lrccccccc}
\hline $\begin{array}{l}\text { River } \\
\text { reach }\end{array}$ & $\begin{array}{r}\text { Bankfull } \\
\text { channel } \\
\text { width } \\
(\mathrm{m})\end{array}$ & $\begin{array}{c}\text { Bankfull } \\
\text { water } \\
\text { depth } \\
(\mathrm{m})\end{array}$ & $\begin{array}{c}\text { Channel } \\
\text { gradient }\end{array}$ & $\begin{array}{c}\text { Median } \\
\text { grain } \\
\text { size } \\
(\mathrm{m})\end{array}$ & $\begin{array}{c}\text { Manning } \\
\text { coefficient }\end{array}$ & $\begin{array}{c}\text { Average } \\
\text { velocity } \\
\left(\mathrm{m} \mathrm{s}^{-1}\right)\end{array}$ & $\begin{array}{c}\text { Channel } \\
\text { discharge } \\
\left(\mathrm{m}^{3} \mathrm{~s}^{-1}\right)\end{array}$ & $\begin{array}{c}q_{\mathrm{b}} \\
\left(\mathrm{kg} \mathrm{s}^{-1} \mathrm{~m}^{-1}\right)\end{array}$ \\
\hline Dari & 200 & 2.0 & 0.0012 & 0.015 & 0.05 & 0.90 & 269.67 & 1.77 \\
Maqu & 400 & 4.0 & 0.0005 & 0.015 & 0.15 & 0.37 & 593.14 & 2.75 \\
Lanmucuo & 20 & 0.8 & 0.0015 & 0.010 & 0.03 & 1.06 & 16.91 & 2.35 \\
Daheba & 50 & 1.5 & 0.0018 & 0.016 & 0.05 & 0.96 & 71.75 & 2.25 \\
\hline
\end{tabular}

outlined below. Channel flow follows the laws of flow continuity, flow resistance, and sediment transport with flow continuity law taking the form:

$$
Q=A V
$$

where $Q, A$, and $V$ are flow discharge $\left(\mathrm{m}^{3} \mathrm{~s}^{-1}\right)$, channel cross-sectional area $\left(\mathrm{m}^{2}\right)$, and average flow velocity $\left(\mathrm{m} \mathrm{s}^{-1}\right)$, respectively, $A=W H, W$ is channel width (m), $H$ is water depth (m).

This study adopts the Manning formula to embody the law of flow resistance for uniform alluvial channel flow:

$V=\frac{1}{n} R^{2 / 3} S^{1 / 2}$

where $R$ is hydraulic radius (m), $R=W H /(2 H+W), S$ is flow energy slope, $n$ is Manning's roughness coefficient. In this study, following Chow (1959), $n=0.050$ if no vegetation in gravel-bed channels at high stages (i.e., Daheba reach), $n=0.030$ in floodplain with short grass (i.e., Lanmucuo River), $n=0.050$ in floodplain with scattered brush and heavy weeds (i.e., Dari River), and $n=0.150$ in floodplain with dense willows at flood stage (i.e., Maqu reach).

Among numerous bedload formulae, the Meyer-Peter and Müller equation has been extensively and successfully applied (Meyer-Peter and Müller, 1948). The modification developed by Wong and Parker (2006) has been used in this study:

$\Phi=3.97(\Psi-0.0495)^{3 / 2}$,

where $\Phi$ and $\Psi$ are the dimensionless bedload transport rate per unit channel width and the dimensionless flow shear stress, respectively, that are defined as

$$
\begin{aligned}
& \Phi=\frac{q_{\mathrm{b}}}{\sqrt{\left(\rho_{\mathrm{s}} / \rho-1\right) g d_{50}^{3}}}, \\
& \Psi=\frac{R S}{\left(\rho_{\mathrm{s}} / \rho-1\right) d_{50}},
\end{aligned}
$$

where $q_{\mathrm{b}}$ is the dimensional bedload transport rate per unit channel width $\left(\mathrm{kg} \mathrm{s}^{-1} \mathrm{~m}^{-1}\right), \rho_{\mathrm{s}}$ is the density of sediments transported $\left(\mathrm{kg} \mathrm{m}^{-3}\right), \rho$ is the density of water $\left(\mathrm{kg} \mathrm{m}^{-3}\right), g$ is the acceleration of gravity $\left(\mathrm{m} \mathrm{s}^{-2}\right)$, and $d_{50}$ is the median sediment size ( $\mathrm{mm})$.

Cross section and water depth were measured based on field survey and remote sensing images (see Table 2). Estimated hydraulic parameters and bedload transport capacity for the four reaches, derived using Eqs. (1)-(5), are summarized in Table 3. Note that channel width is effective bankfull width in the flood season, not valley width. The adopted mean grain size is lower than bed sediment size. Results shown here are considered to be approximations, and are analyzed solely in relational rather than absolute terms. Results show that the bedload transport capacity of the four reaches from high to low is as follows: Maqu, Lanmucuo, Daheba and Dari reaches.

\section{Effect of vegetation and bedload capacity on channel stability}

\subsection{Dari reach (braided-anabranching river with grass and shrub cover)}

The Dari reach is a wide semi-braided and semianabranching channel, where the channel width is up to $1600 \mathrm{~m}$ (Fig. 2 - R1a). Some large stable gravel bars or islands have a dense grass and sparse shrub cover. Many unstable bars with low vegetation cover are subjected to recurring erosion and channel adjustment. Vegetation may inhibit erosion and enhance bar stability at middle flood stage, but the resistance effect of vegetation at high flood stage is very limited. As a result, the whole channel may be eroded at high flow stage, resulting in disordered patterns of mid-channel gravel bars. The estimated bedload transport capacity per unit channel width is $1.77 \mathrm{~kg} \mathrm{~m}^{-1} \mathrm{~s}^{-1}$ for $2.0 \mathrm{~m}$ water depth (see Table 2). If the water depth increases to $3.0 \mathrm{~m}$ in the flood season, bedload transport capacity per unit width significantly increases up to $14.93 \mathrm{~kg} \mathrm{~m}^{-1} \mathrm{~s}^{-1}$. It is likely that these flow depths cause intense erosion that divides the stable bars into many unstable bars.

Figure $4 \mathrm{a}$ and $\mathrm{b}$ show monthly stage-discharge relationships for 1968 and 1984, respectively. Since the Dari reach is a multi-thread channel system, the stage-discharge relationship is not a single function relationship. In non-flood 

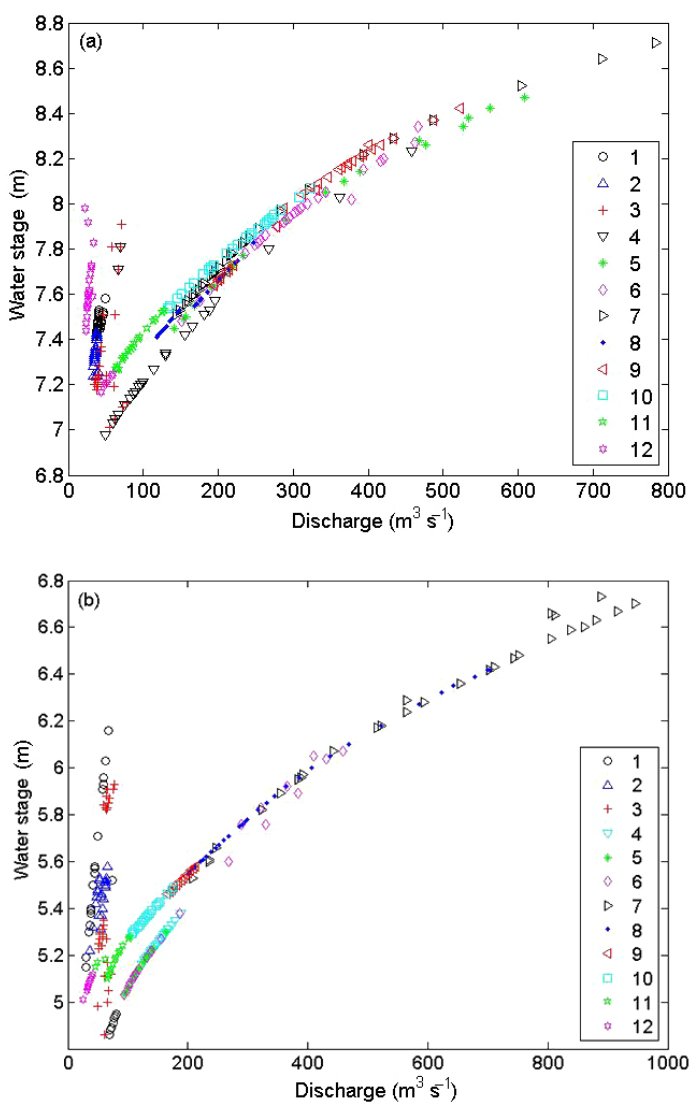

Figure 4. Monthly stage-discharge relationships for Jimai hydrological station in the Dari reach (a) 1968 (b) 1984 (note: number refers to month, e.g., 1 for January and 12 for December).

months (December, January, February, March, and April) the river bed is frozen. May and November are pivotal times in the stage-discharge relationship (the former reflects ice melt, the latter freezing). In flood months (June, July, August, and September) the stage-discharge relationship adjusts due to strongly erosion and deposition within the channel. The stage-discharge data (June, July, August, and September) in the 1968 and 1984 are to run non-linear regression (power function, $Z=a \cdot Q^{\mathrm{b}}, Z$ is water stage $(\mathrm{m}), Q$ is discharge $\left(\mathrm{m}^{3} \mathrm{~s}^{-1}\right), a$ is the coefficient, and $b$ is the exponent). Two coefficients of $a(b)$ in 1968 are 4.7 (0.09), $4.8(0.09)$, 5.4 (0.07), and 4.5 (0.10) for June, July, August, and September, respectively; and accordingly, 2.9 (0.12), 2.8 (0.13), $3.0(0.12)$, and $3.5(0.09)$ in 1984. The results of the regression show that $a$ obviously decreased and $b$ was almost unchanged, indicating the increase of water depth slowed down with the incoming discharge increasing from 1968 to 1984 because the sediment deposition leaded to the wider channel year by year.

For instance, different discharges for the same flow stage in June and July 1968 are considered to reflect erosion of the channel (Fig. 4a). In the other instance shown here, the max- imum discharge in 1984 occurred in July (Fig. 4b), probably marking the transition from erosion to deposition phases. The geomorphological significance of the two different trends is shown in Fig. 4a and b (i.e., the trend formed by the data in March and April against the trend formed). Also, there is a difference between the high scatter trend for low discharges (probably low flood stages) and regular trends for high discharges (probably high flood stages) because the water submerged the bars in high discharge and the multi-thread channels appears in low discharges. The Dari reach is defined in this study as semi-braided and semi-anabranching since vegetation (grass and some shrubs) partially develops on channel bars, and bars are relatively stable during low and middle flood stages, whereas they are prone to change during high flood stages.

Figure 5 shows the stage-discharge relationships of the Upper Yellow River at the Dari from June to September in 1964-1984. Apparently, the stages of 1975 are out of line with 1978, perhaps indicating that the elevation benchmark of the station changed in 1976 or 1977. In the same month of different years, the stage-discharge relationship does not have a simple corresponding relation, especially in August and September. This may reflect (1) responses of the channel bed to strong deposition in June and July, and thereafter the high stage corresponds to low discharge such as August in 1978-1984 and September in 1964-1975; (2) the channel bed strongly erodes in June and July, and thereafter the high stage corresponds to high discharge such as August in 19641975 and September in 1978-1984. Overall, Fig. 2 R1a and b indicate that the channel of the Dari reach is quite unstable during the flood season, with erosion and deposition changing the stage-discharge relationship. A sketch showing how flow erosion divides bars and deposits to form new bars is shown in Fig. 6. The stage-discharge data in July from 1964 1984 are to run power function regression $\left(Z=a \cdot Q^{\mathrm{b}}\right)$. Two coefficients of $a(b)$ are $5.3(0.08)$ in 1964, $4.7(0.10)$ in 1965, $5.4(0.07)$ in 1966, $4.8(0.09)$ in 1968, $5.2(0.07)$ in 1969, $5.3(0.07)$ in $1970,5.3(0.06)$ in $1973,4.6(0.10)$ in 1975 , $2.9(0.11)$ in 1978, $2.7(0.13)$ in 1979, $2.7(0.13)$ in 1980, $2.4(0.15)$ in 1981, and $2.8(0.13)$ in 1984. Obviously, this difference of $a(b)$ is represented by the two different trends of the data before and after 1976, i.e., $a$ decreased and $b$ increased.

\subsection{Maqu reach (anabranching river with tree cover)}

The Maqu reach in the wide Ruoergai basin is covered by a dense tress (Salix atopantha) and has a stable anabranching channel planform (Fig. 2 R2a). It is postulated that a herb and shrub cover gradually supports the stabilization of new bars, facilitating sediment deposition on the body of the bar during low and middle flood stages, and protects the bar from erosion at high flood stages. Subsequent development of trees presents a tall green barrier in the flood period. Although the water floods trees, their density induces sufficient resistance 

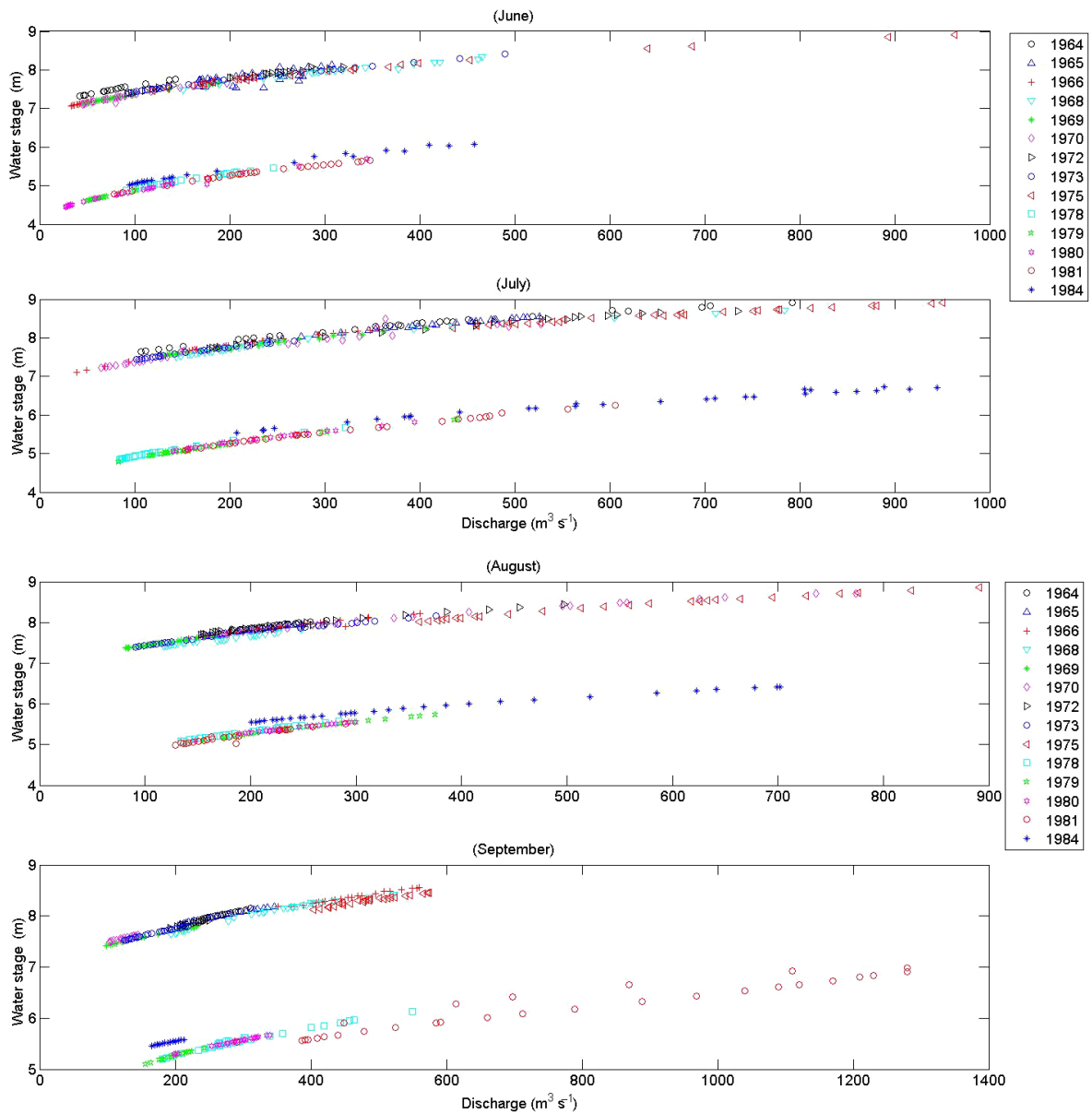

Figure 5. Annual stage-discharge relationship (1964-1984) of the Dari reach in Jimai hydrological station.

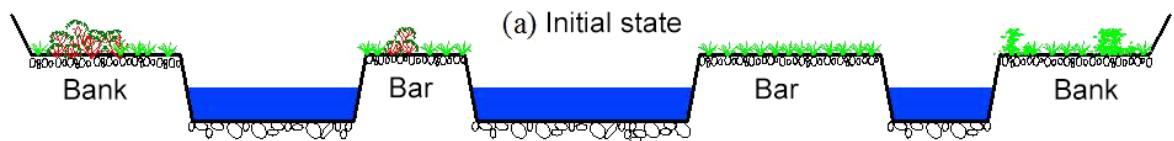

(b) Deposition
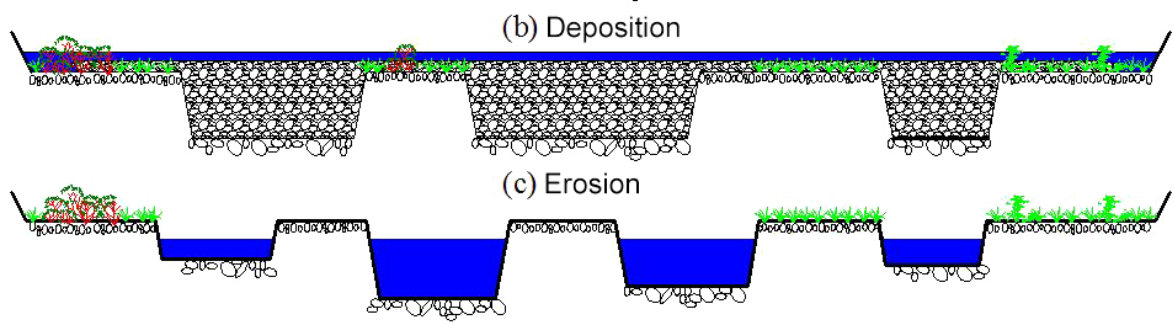

Figure 6. Sketch of channel bed deposition and erosion in flood season in the Dari reach.

to decrease the flow velocity and trap fine sand and gravel on the body of the bar. Therefore, this anabranching channel system is basically stable over a decadal timescale.

Water stage change at the Maqu station from 1959 to 1970 is shown in Fig. 7. The stage peak occurs in July and September. The maximum difference of $2.43 \mathrm{~m}$ occurred between June and September in 1963. If the water depth increases to $8.0 \mathrm{~m}$ from $4.0 \mathrm{~m}$, bedload transport capacity increases to $18.52 \mathrm{~kg} \mathrm{~s}^{-1} \mathrm{~m}^{-1}$ from $2.75 \mathrm{~kg} \mathrm{~s}^{-1} \mathrm{~m}^{-1}$. As a result, the branching channel bed may erode if the transport capacity exceeds upstream sediment supply. However, protection by trees is strong enough to inhibit erosion of bars. On the contrary, if the upstream sediment supply surpasses the transport capacity, increasing bed deposition with flow stage fur- 


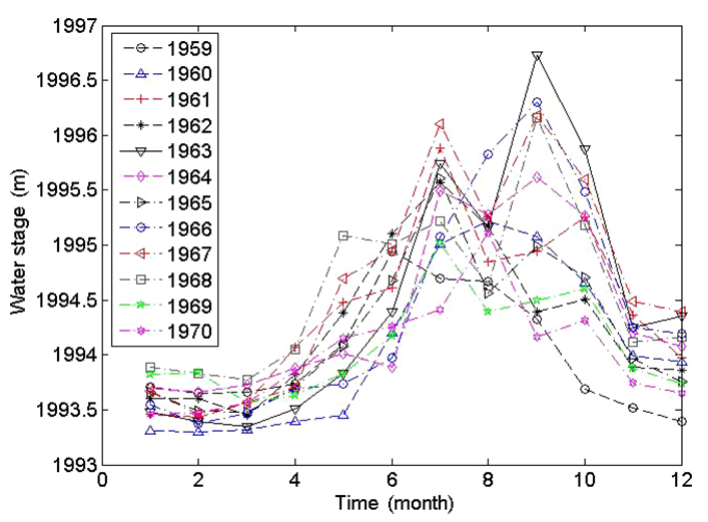

Figure 7. Monthly stage change of the Maqu hydrological station (1959-1970).

ther increases the transport capacity of the reach. This agrees with analyses by Huang and Nanson (2007), who stated that anabranching channels can achieve the optimal transport efficiency without increasing bed gradient. Even though these reaches may appear to promote deposition on the channel bed during extreme floods (see Fig. 8), the flow erodes the bed later in the flood season, thereby maintaining an equilibrium cross section. As a result, the anabranching channel of the Maqu reach maintains a long-term stable situation.

\subsection{Lanmucuo River (passive meandering river with meadow cover)}

The Lanmucuo River is a typical meandering river covered by dense meadow. Although typically characterized by large bends in a flat valley, mid-channel gravel bar covered by herbs sometimes form at the apex of bends (Fig. 2 R3a). The meandering channel and bars are very stable because of low sediment supply in the flood season and good vegetation coverage. The tight root-soil complex on concave banks inhibits flow scour. When cantilevered bank failures do occur, slump blocks restrict further erosion of the bank. Grass develops on the point bars of convex banks. When the overbank flow submerges the point bar, the herbaceous vegetation can increase flow resistance and promote fine sand deposition (Fig. 9), thereby maintaining channel geometry with a relatively low migration rate. Growth of herbs on mid-channel bars (Fig. 2 R3a) helps to increase the flow resistance and trap fine sediment, facilitating channel stability.

\subsection{Daheba River (unvegetated braided river)}

The gravel bed of the Daheba River is characterized by deposition in the flood season and erosion in the non-flood season. This makes it difficult for vegetation to develop on bars and banks of the braided channels. Figure 10 shows morphological changes of the riverbed before and after the flood season in 2005. The main branching and sub-branching channels of the channel completely changed, with an initial phase

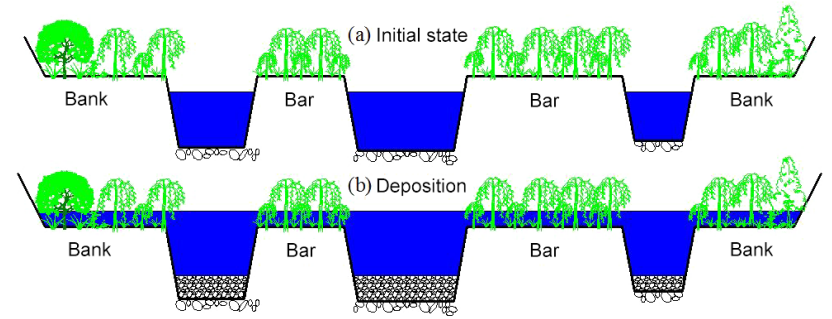

Figure 8. Sketch of branching channel deposition and stage increasing in flood season in the Maqu reach.

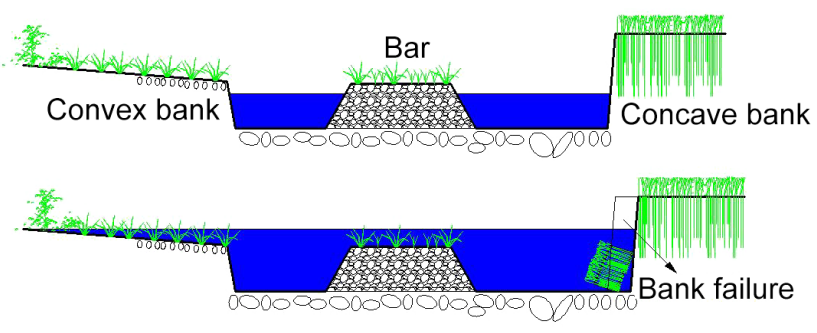

Figure 9. Sketch of submerged bend apex with a mid-channel bar in the Lanmucuo River.

of sediment deposition followed by flood-induced division of bars and the re-emergence of a multi-thread braided system. Table 3 shows derived estimates of the bedload transport capacity per width, $q_{\mathrm{b}}=2.25 \mathrm{~kg} \mathrm{~s}^{-1} \mathrm{~m}^{-1}$. This capacity is seemingly unable to efficiently transport the excess sediment supply from upstream. As a result, serious deposition occurs along the Daheba River in the flood season.

Adjustments to channel geometry as a result of erosion and deposition processes before, during, and after the flood season are shown in Fig. 11. The elevation of the riverbed on 29 July 2009 was $0.27 \mathrm{~m}$ higher than on 1 April 2009. Other than a slight erosion of the left bank, the subsequent phase was depositional, with up to $1.59 \mathrm{~m}$ of aggradation occurring by 23 October 2009. The elevation of the riverbed was increased by $0.27 \mathrm{~m}$ after the flood season in 2010 . The elevation of the riverbed in 1 July 2011 was $0.26 \mathrm{~m}$ higher than on 29 April 2011. Trivial deposition occurred from 1 to 8 July, but $0.24 \mathrm{~m}$ of erosion occurred by $23 \mathrm{July}$, with subsequent deposition of $0.27 \mathrm{~m}$ by 23 October. As a result, the riverbed elevation was $0.24 \mathrm{~m}$ higher after flood season in 2011, but multiple phases of deposition and erosion has occurred. The deposition-erosion-deposition phases may reflect lower bedload transport capacity relative to sediment supply in the early flood season, but widespread deposition increases the local bed slope, thereby increasing bedload transport capacity. According to Eq. (3), a $10 \%$ increase in bed slope increases the transport capacity by $85 \%$ in Daheba reach, so bed erosion occurs again. Bed erosion decreases the bed slope until the transport capacity has adjusted to reduced sediment supply, thereby inducing riverbed deposition once 


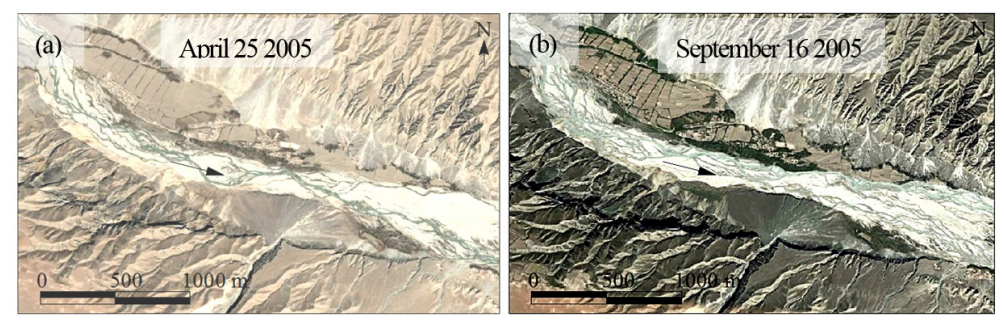

Figure 10. Braided channel evolution of the middle Daheba River in 2005 (a) in non-flood season, (b) in flood season.
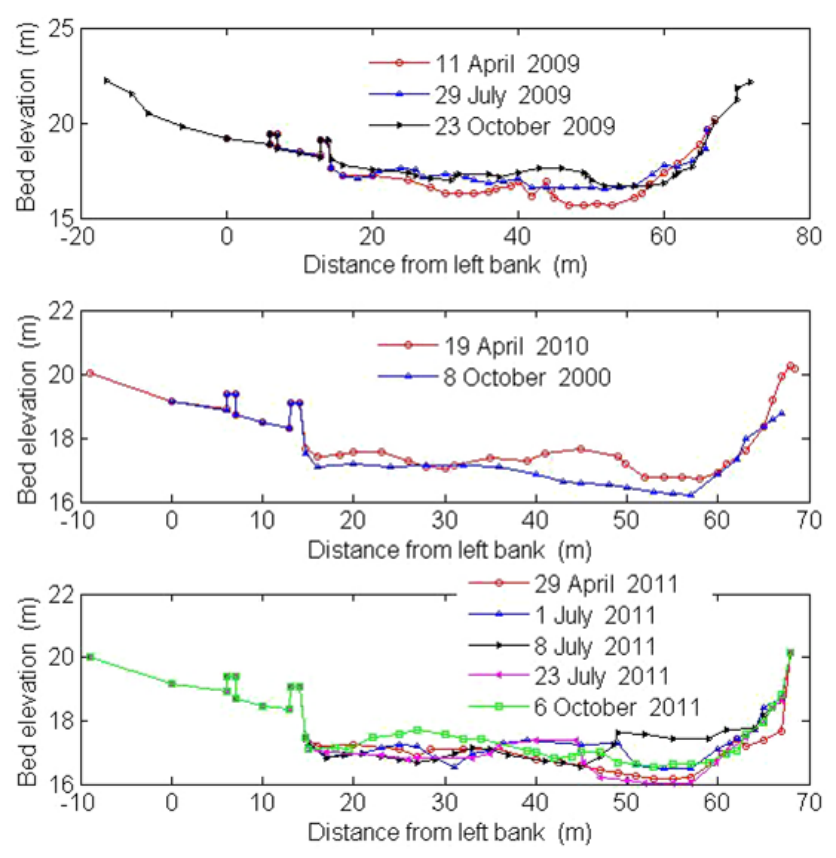

Figure 11. Elevation change of cross section in Shangcun hydrological station (2009-2011) (left for left bank, right for right bank).

more. Consequently, alterative deposition and erosion leads to the extreme instability in the middle and lower Daheba River.

\section{Discussion and conclusions}

This study has outlined the complex interplay between flow and sediment supply in the flood season, and the geomorphic/hydrodynamic role of vegetation cover on the valley floor, as determinants of channel morphodynamics/stability and bedload transport capacity for four alluvial reaches of the Yellow River source zone. Although the elevation of four reaches is different (Dari is $3960 \mathrm{~m}$, Maqu is $3465 \mathrm{~m}$, Lanmucuo River is $3604 \mathrm{~m}$, and Daheba is $2832 \mathrm{~m}$ ), the precipitation, temperature, and bed sediment size are basically similar (Yu et al., 2014). Nevertheless, vegetation coverage in the four reaches is quite different. The Dari reach (anabranching-braided) has a herb and shrub cover, the
Maqu (anabranching) reach has trees, the Lanmucuo River (meandering) has meadow, and the Daheba River (braided) has no vegetation cover. As shown elsewhere, bar morphodynamics vary markedly for differing planform types, with key differences outlined here for braided, anabranching, and meandering channels (cf., Hooke, 1986; Kleinhans, 2010; Kleinhans and van den Berg, 2010; Church and Ferguson, 2015). Bar development and stability reflect the ability of vegetation to trap sediments and stabilize banks, which in turn is directly influenced by flow energy relationships (i.e., these are mutual adjustments; Corenblit et al., 2007; Gurnell et al., 2012; Gurnell, 2014; Osterkamp and Hupp, 2010; Pietsch and Nanson, 2011). In this study, riparian vegetation and its root network are considered to restrict channel width and increase hydraulic efficiency, inducing greater bedload transport capacity in multi-thread channels (Allmendinger et al., 2005; Huang and Nanson, 2007). Islands and floodplains are able to trap more fine-grained sediment in the flood season, enhancing the longer-term (decadal) stability of anabranching channels, as shown by the stable islands of the Maqu reach.

Relative to the passive (resisting) role of vegetation, bedload transport actively affects short-term patterns and rates of bed erosion and deposition. This, in turn, is affected by relationships between the flow regime (especially flood events and formative flows) and the influence of sediment supply upon bedload transport for differing river types (Church and Ferguson, 2015; Dunne et al., 2010). The supply of bed material sediment to an alluvial channel accelerates the growth of longitudinal, transverse, and point bars, thereby enhancing thalweg development and locally increasing flow velocity. Non-equilibrium between sediment supply and transport induces local channel instability, accentuating either bed erosion or deposition (Jansen and Nanson, 2010; Nanson and Huang, 2008). In this study, a channel stability gradient accords with both sediment movement and vegetation cover, wherein bedload transport capacity (a function of bed slope, hydraulic geometry, and sediment particle size) is related to the influence of riparian vegetation upon channel geometry/planform. We contend that the differing vegetation cover and planform response reflect the delicate balance between erosion and deposition on the channel bed and bank as influenced by bedload sediment supply in the flood season. Only 
when the bedload transport capacity is equivalent or greater than sediment supply does vegetation act as a key determinant of channel stability.

Author contributions. Zhi Wei Li and Guo An Yu designed and conducted the field investigations. Gary Brierley and Zhao Yin Wang supervised the research and helped to contextualize the findings. Zhi Wei Li prepared the manuscript with contributions from all co-authors.

Acknowledgements. This study is funded by the CRSRI Open Research Program (program CKWV2016369/KY), Alexander von Humboldt Foundation, the Natural Science Foundation of China (NSFC, 41571009; 41330751; 91547112; 91547113), and the Key Laboratory of Water Sediment Sciences and Water Disaster Prevention of Hunan Province (2016SS04). X. Z. Wang, C. D. Zhang, and X. D. Zhou are acknowledged for field assistance (2011-2014). We deeply appreciate the constructive comments and suggestions from two reviewers (Peng Gao and M. Coenders-Gerrits).

Edited by: G. Blöschl

Reviewed by: P. Gao and M. Coenders-Gerrits

\section{References}

Abernethy, B. and Rutherfurd, I. D.: The distribution and strength of riparian tree roots in relation to riverbank reinforcement, Hydrol. Process., 15, 63-79, 2001.

Allmendinger, N. E., Pizzuto, J. E., Potter Jr., N., Johnson, T. E., and Hession, W. C.: The influence of riparian vegetation on stream width, eastern Pennsylvania, USA, GSA Bulletin, 117, 229-243, 2005.

Ashmore, P. E.: How do gravel-bed river braid?, Can. J. Earth Sci., 28, 326-341, 1991.

Ashworth, P. J.: Mid-channel bar growth and its relationship to local flow strength and direction, Earth Surf. Proc. Land., 21, 103-123, 1996.

Ashworth, P. J. and Lewin, J.: How do big rivers come to be different?, Earth-Sci. Rev., 114, 84-107, 2012.

Ashworth, P. J., Best, J. L., Roden, J. E., Bristow, C. S., and Klaassen, G. J.: Morphological evolution and dynamics of a large, sand braid-bar, Jamuna River, Bangladesh, Sedimentology, 47, 533-555, 2000.

Ashworth, P. J., Sambrook Smith, G. H., Best, J. L., Bridge, J. S., Lane, S. N., Lunt, I. A., Reesink, A. J. H., Simpson, C. J., and Thomas, R. E.: Evolution and sedimentology of a channel fill in the sandy braided South Saskatchewan River and its comparison to the deposits of an adjacent compound bar, Sedimentology, 58, 1860-1883, 2011.

Beechie, T. J., Sear, D. A., Olden, J. D., Pess, G. R., Buffington, J. M., Moir, H., Roni, P., and Pollock, M. M.: Process-based principles for restoring river ecosystems, BioScience, 60, 209-222, 2010.

Best, J. L., Ashworth, P. J., Bristow, C. S., and Roden, J. E.: Threedimensional sedimentary architecture of a large, mid-channel sand braid bar Jamuna River, Bangladesh, J. Sediment. Res., 73, 516-530, 2003.

Blue, B., Brierley, G. J., and Yu, G. A.: Geodiversity in the Yellow River source zone, J. Geogr. Sci., 23, 775-792, 2013.

Bridge, J. S.: Description and interpretation of fluvial deposits: a critical perspective, Sedimentology, 40, 801-810, 1993.

Bridge, J. S.: Rivers and Floodplains: Forms Processes and Sedimentary Record, Blackwell Publishing, London, 2003.

Brierley, G .J.: Bar sedimentology of the Squamish River, British Columbia: Definition and application of morphostratigraphic units, J. Sediment. Petrol., 61, 211-225, 1989.

Brierley, G. J.: Floodplain sedimentology of the Squamish River, British Columbia: relevance of element analysis, Sedimentology, 38, 735-750, 1991.

Brierley, G. J.: Channel morphology and element assemblages: A constructivist approach to facies modelling, in: Recent advances in fluid mechanics and alluvial stratigraphy, edited by: Dawson, M. and Carling, P. A., Wiley Interscience, Chichester, 1996.

Brierley, G. J. and Fryirs, K. A.: Geomorphology and River Management: Applications of the River Styles Framework, Blackwell Publications, Oxford, UK, 2005.

Brierley, G. J. and Hickin, E. J.: Channel planform as a noncontrolling factor in fluvial sedimentology: The case of the Squamish River floodplain, British Columbia, Sediment. Geol., 75, 67-83, 1991.

Brierley, G. J., Li, X. L., Cullum, C., and Gao, J.: Landscape and ecosystem diversity, dynamics and management in the Yellow River source zone, Springer, Switzerland, 2016.

Burge, L. M.: Stability, morphology and surface grain size patterns of channel bifurcation in gravel-cobble bedded anabranching, Earth Surf. Proc. Land., 31, 1211-1226, 2006.

Carling, P., Jansen, J., and Meshkova, L.: Multichannel rivers: their definition and classification, Earth Surf. Proc. Land., 39, 26-37, 2014.

Chow, V. T.: Open Channel Hydraulics, McGraw-Hill, New York, 1959.

Church, M. and Ferguson, R. I.: Morphodynamics: River beyond steady state, Water Resour. Res., 51, 1883-1897, doi:10.1002/2014WR016862, 2015.

Church, M. and Rice, S. P.: Form and growth of bars in a wandering gravel-bed river, Earth Surf. Proc. Land., 34, 1422-1432, 2009.

Corenblit, D., Tabacchi, E., Steiger, J., and Gurnell, A. M.: Reciprocal interactions and adjustments between fluvial landforms and vegetation dynamics in river corridors: a review of complementary approaches, Earth-Sci. Rev., 84, 56-86, 2007.

Corenblit, D., Baas, A. C. W., Bornette, G., Bornette, G., Darrozes, J., Delmotte, S., Francis, R. A., Gurnell, A. M., Julien, F., Naiman, R. J., and Steiger, J.: Feedbacks between geomorphology and biota controlling earth surface processes and landforms: A review of foundation concepts and current understandings, Earth-Sci. Rev., 106, 307-331, 2011.

Coulthard, T. J.: Effects of vegetation on braided stream patterns and dynamics, Water Resour. Res., 41, W04003, doi:10.1029/2004WR003201, 2005.

Dunne, T., Constantine, J. A, and Singer, M. B.: The role of sediment transport and sediment supply in the evolution of river channel and floodplain complexity, Transactions, Japanese Geomorphological Union, 31-32, 155-170, 2010. 
Eaton, B. C. and Church, M.: Predicting downstream hydraulic geometry: A test of rational regime theory, J. Geophys. Res., 112, F03025, doi:10.1029/2006JF000734, 2007.

Eaton, B. C. and Giles, T. R.: Assessing the effect of vegetationrelated bank strength on channel morphology and stability in gravel-bed streams using numerical models, Earth Surf. Proc. Land., 34, 712-724, 2009.

Eaton, B. C., Church, M., and Millar, R. G.: Rational regime model of alluvial channel morphology and response, Earth Surf. Proc. Land., 29, 511-529, 2004.

Eaton, B. C., Millar, R. G., and Davidson, S.: Channel patterns: braided, anabranching, and single-thread, Geomorphology, 120, 353-364, 2010.

Fryirs, K. A. and Brierley, G. J.: Geomorphic analysis of river systems: an approach to reading the landscape, Wiley-Blackwell, Chichester, UK, 2012.

Gradzinski, R., Baryla, J., Doktor, M., Gmur, D., Gradzinski, M., Kedzoir, A., Paszkowski, M., Soja, R., Zielinski, T., and Zurek, S.: Vegetation-controlled modern anastomosing system of the upper Narew River (NE Poland) and its sediments, Sediment. Geol., 157, 253-276, 2003.

Gran, K. and Paola, C.: Riparian vegetation controls on braided stream dynamics, Water Resour. Res., 37, 3275-3283, 2001.

Gurnell, A. M.: Plants as river system engineers, Earth Surf. Proc. Land., 39, 4-25, 2014.

Gurnell, A. M., Petts, G. E., Hannah, D. M., Smith, B. P., Edwards, P. J., Kollmann, J., Ward, J. V., and Tockner, K.: Riparian vegetation and island formation along the gravel-bed Fiume Tagliamento, Italy, Earth Surf. Proc. Land., 26, 31-62, 2001.

Gurnell, A. M., Bertoldi, W., and Corenblit, D.: Changing river channels: The roles of hydrological processes, plants and pioneer fluvial landforms in humid temperate, mixed load, gravel bed rivers, Earth-Sci. Rev., 111, 129-141, 2012.

Hickin, E. J.: Vegetation and river channel dynamics, Can. Geogr., 28, 111-126, 1984.

Hooke, J .M.: The significance of mid-channel bars in an active meandering river, Sedimentology, 33, 839-850, 1986.

Hooke, J. M.: Variations in flood magnitude-effect relations and the implications for flood risk assessment and river management, Geomorphology, 251, 91-107, 2015.

Hooke, J. M. and Yorke, L.: Channel bar dynamics on multi-decadal timescales in an active meandering river. Earth Surf. Proc. Land., 36, 1910-1928, 2011.

Huang, H. Q. and Nanson, G. C.: Why some alluvial rivers develop an anabranching pattern, Water Resour. Res., 43, W07441, doi:10.1029/2006WR005223, 2007.

Hupp, C. R. and Osterkamp, W. R.: Riparian vegetation and fluvial geomorphic processes, Geomorphology, 14, 277-295, 1996.

Jang, C. L. and Shimizu, Y.: Vegetation effects on the morphological behavior of alluvial channels, J. Hydraul. Res., 45, 763-772, 2007.

Jansen, J. D. and Nanson, G. C.: Anabranching and maximum flow efficiency in Magela Creek, northern Australia, Water Resour. Res., 40, W04503, doi:10.1029/2003WR002408, 2004.

Jansen, J. D. and Nanson, G. C.: Functional relationships between vegetation, channel morphology, and flow efficiency in an alluvial (anabranching) river, J. Geophys. Res., 115, F04030, doi:10.1029/2010JF001657, 2010.
Jerolmack, D. J. and Mohrig, D.: Conditions for branching in depositional rivers, Geology, 35, 463-466, 2007.

Kleinhans, M. G.: Sorting out river channel patterns, Prog. Phys. Geogr., 34, 287-326, 2010.

Kleinhans, M. G. and van den Berg, J. H.: River channel and bar patterns explained and predicted by an empirical and a physicsbased method, Earth Surf. Proc. Land., 36, 721-738, 2010.

Latrubesse, E. M.: Patterns of anabranching channels: The ultimate end-member adjustment of mega rivers, Geomorphology, 101, 130-145, 2008.

Latrubesse, E. M. and Franzinelli, E.: The Holocene alluvial plain of the middle Amazon River, Brazil, Geomorphology, 44, 241257, 2002.

Lewin, J. and Ashworth, P. J.: Defining large river channel patterns: Alluvial exchange and plurality, Geomorphology, 215, 83-98, 2014.

Li, Z. W., Wang, Z. Y., Pan, B. Z., Du, J., Brierley, G., Yu, G. A., and Blue, B.: Analysis of controls upon channel planform at the First Great Bend of the Upper Yellow River, Qinghai-Tibet Plateau, J. Geogr. Sci., 23, 833-848, 2013.

Luchi, R., Zolezzi, G., and Tubino, M.: Modelling mid-channel bars in meandering channels, Earth Surf. Proc. Land., 35, 902-917, 2010.

Makaske, B.: Anastomosing rivers: a review of their classification, origin and sedimentary products, Earth-Sci. Rev., 53, 149-196, 2001.

McBride, M., Hession, W. C., Rizzo, D. M., and Thompson, D. M.: The influence of riparian vegetation on near-bank turbulence: a flume experiment, Earth Surf. Proc. Land., 32, 2019-2037, 2007.

McGowen, J. H. and Garner, L.: Physiographic features and stratification types of coarse-grained point bars: Modern and ancient examples, Sedimentology, 14, 77-111, 1970.

Mertes, L., Dunne, T., and Martinelli, L.: Channel floodplain geomorphology along the Solimões-Amazon River, Brazil, Geol. Soc. Am. Bull., 108, 1089-1107, 1996.

Meyer-Peter, E. and Müller, R.: Formulas for bed load transport, paper presented at 2nd Meeting, International Association for Hydraulic Environmental Engineering and Research, Madrid, 1948.

Millar, R. G.: Influence of bank vegetation on alluvial channel patterns, Water Resour. Res., 36, 1109-1118, 2000.

Murray, A. B. and Paola, C.: Modelling the effect of vegetation on channel pattern in bedload rivers, Earth Surf. Proc. Land., 28, 131-143, 2003.

Nanson, G. C. and Huang, H. Q.: Least action principle, equilibrium states, iterative adjustment, and the stability of alluvial channels, Earth Surf. Proc. Land., 33, 923-942, 2008.

Nanson, G. C. and Knighton, A. D.: Anabranching rivers: their cause, character and classification, Earth Surf. Proc. Land., 21, 217-239, 1996.

Nicholas, A. P., Ashworth, P. J., Smith, G. H. S., and Sandbach, S. D.: Numerical simulation of bar and island morphodynamics in anabranching megarivers, J. Geophys. Res.-Ea. Surf., 118, 20192044, 2013.

Osterkamp, W. R. and Hupp, C. R.: Fluvial processes and vegetation-Glimpses of the past, the present, and perhaps the future, Geomorphology, 116, 274-285, 2010.

Pietsch, T. J. and Nanson, G. C.: Bankfull hydraulic geometry: the role of in-channel vegetation and downstream declining discharges in the anabranching and distributary channels of the 
Gwydir distributive system, southeastern Australia, Geomorphology, 129, 152-165, 2011.

Reesink, A. J., Ashworth, P. J., Sambrook Smith, G. H., Best, J. L., Parsons, D. R., Amsler, M. L., Hardy, R. J., Lane, S. N., Nicholas, A. P., Orfeo, O., Sandbach, S. D., Simpson, C. J., and Szupiany, R. N.: Scales and causes of heterogeneity in bars in a large multichannel river: Río Paraná, Argentina, Sedimentology, 61, 10551085, 2014.

Sambrook, S. G. H., Ashworth, P. J., Best, J. L., Lunt, I. A., Orfeo, O., and Parsons, D. R.: The sedimentology and alluvial architecture of a large braid bar Río Paraná, Argentina, J. Sediment. Res., 79, 629-642, 2009.

Smith, N. D.: Sedimentology and bar formation in the Upper Kicking Horse River, a braided outwash stream, J. Geol., 82, 205-223, 1974.

Song, X. L. and Bai, Y. C.: A new empirical river pattern discriminant method based on flow resistance characteristics, Catena, 135, 163-172, 2015.

Tadaki, M., Brierley, G., and Cullum, C.: River classification: theory, practice, politics, Wiley Interdisc. Rev. Water, 1, 349-367, 2014.
Tal, M. and Paola, C.: Effects of vegetation on channel morphodynamics: results and insights from laboratory experiments, Earth Surf. Proc. Land., 35, 1014-1028, 2010.

Task Force on Bed Forms in Alluvial Channels: Nomenclature for Bed Forms in Alluvial Channels, J. Hydraul. Div., 92, 51-64, 1966.

Tooth, S. and Nanson, G. C.: The role of vegetation in the formation of anabranching channels in an ephemeral river, Northern plains, arid central Australia, Hydrol. Process., 14, 3099-3117, 2000.

Wang, S. J., Chen, Z. Y., and Smith, D. G.: Anastomosing river system along the subsiding middle Yangtze River basin, southern China, Catena, 60, 147-163, 2005.

Wong, M. and Parker, G.: Reanalysis and correction of bed load relation of Meyer-Peter and Müller using their own database, J. Hydraul. Eng., 132, 1159-1168, 2006.

Yu, G. A., Brierley, G., Huang, H. Q., Wang, Z., Blue, B., and Ma, Y. X.: An environmental gradient of vegetative controls upon channel planform in the source region of the Yangtze and Yellow Rivers, Catena, 119, 14-153, 2014. 